\title{
HABITAT VULNERABILITY \\ FOR THE NILE CROCODILE (CROCODYLUS NILOTICUS) \\ IN NASSER LAKE \\ (EGYPT)
}

Ashraf Hussein Ibrahim SALEM*

* Nature Conservation Sector, South Area Protectorates, Environmental Affairs Agency, Cairo, Egypt, ashraf2404@yahoo.com

vulnerability.

KEYWORDS: Egypt, Nasser Lake, crocodiles, breeding season, habitats

\section{ABSTRACT}

The study presents the results of a field investigation of the crocodile nesting sites on Lake Nasser, observed during the breeding season 2009-2010. A relatively low number of nesting sites was found, explained by the intensity of anthropogenic activity in the area and by the low water levels of Lake Nasser. Based on analysis of satellite imaging and its correlation with the biotope data of the lake shores, a classification system of habitats and of their suitability for crocodile nesting was established. Correlated with land use information, the results can lead to the identification of potential nesting sites for the Nile crocodile, establishing a legal protection system for such habitats.

ZUSAMMENFASSUNG: Die Anfälligkeit der Bruthabitate des Nilkrokodils (Crocodilus niloticus) im Nasser See (Ägypten).

Vorliegende Untersuchung umfasst die Ergebnisse einer Feldforschungskampagne betreffend die in der Paarungszeit 2009-2010 beobachteten Nilkrokodile aus dem Nasser See. Es wurde eine relativ geringe Zahl von Nestern entdeckt, was auf die Intensität menschlicher Tätigkeiten sowie den niedrigen Wasserstand zurückzuführen ist. Aufgrund der Bearbeitung von Satellitbildaufnahmen und deren Korrelation mit den Biotopdaten der Ufer wurde ein Klassifikationssystem der Habitate hinsichtlich ihrer Kapazität der Beherbergung von Korkodilnestern erstellt. Korreliert mit den Landnutzungsdaten können die Ergebnisse zur Identifizierung potentieller Brutplätze des Nilkrokodils führen und damit die Grundlage eines legalen Schutzsystems dieser Habitate liefern.

REZUMAT: Vulnerabilitatea habitatului de cuibărit a crocodilului de Nil (Crocodilus niloticus) în lacul Nasser (Egipt).

Studiul prezintă rezultatele unei campanii de teren asupra crocodililor din lacul Nasser, observaţi în sezonul de împerechere 2009-2010. Un număr relativ mic de cuiburi a fost descoperit, fapt explicat de intensitatea activităţilor antropice şi de nivelul scăzut al lacului Nasser. Pe baza prelucrării imaginilor satelitare și a corelării acestora cu datele de biotop aferente malurilor a fost stabilit un sistem de clasificare a habitatelor, în funcție de capacitatea acestora de a găzdui cuiburi de crocodili. Corelate cu datele de utilizare a terenurilor, rezultatele pot conduce la identificarea potenţialelor locuri de cuibărire ale crocodilului de Nil, punând bazele unui sistem de protecție legală al acestor habitate. 


\section{INTRODUCTION}

The major conflict between man and crocodile for living space can only be understood once each of the living species necessities is investigated. The fishermen camps and Bedouin communities along the Nasser Lake shoreline require resources from the lake and while acquiring these resources, the community members create disturbances to crocodile life, including their nesting activities. To facilitate the identification of areas of human disturbance and their intensities, the activities and their timing in relation to crocodile nesting need to be assessed in Nasser Lake area.

Throughout the history, humanity's tendency to occupy areas in close proximity to resources and open spaces is obvious. This occupancy is usually detrimental to some natural resources, as human populations continue to increase, while the living space becomes smaller and smaller in time. The inability of man to use the natural resources without depleting stocks or disturbing natural processes is a concern for our world, especially for some species that inhabit it. The Nasser Lake crocodile is just one of the species suffering from human disturbances.

The Nasser Lake in Egypt is certainly an unique water reservoir which not only provides a continuous water supply to Egypt, but also supports many local communities, fishermen and others as well as a huge diversity of fauna and flora; fishing, grazing, tourism, plant collection, mining and agriculture are just some of the common activities associated with the surrounding communities along the shoreline.

The Nile crocodile, Crocodylus niloticus, is the fresh water top predator throughout Nasser Lake and in a large part of Africa. They are strict carnivores and relentless predators throughout their lives as they grow from $30 / 33 \mathrm{~cm}$ in total length up to $6.20 \mathrm{~m}$ and weighing over $750 \mathrm{~kg}$. Like all true crocodiles, this is a tropical/sub-tropical species, rarely found where mean water temperatures are below $15-20^{\circ} \mathrm{C}$ (upland areas and the south of the continent), being rare in moist forest and extensive swamps, where it is replaced by Crocodylus cataphractus and Caiman crocodylus. Its absence from these habitats is strongly linked to those geomorphological characteristics of rivers and lakes which have a directly influence on the nesting behavior (Hutton and Games, 1992).

The Nile crocodile prefers permanent, still or slow-moving water with high, sunny, sandy banks above flood levels and enough vegetation to provide shade and shelter. Much of rural Africa does not possess modern infrastructure and western-style economic development, water being a scarce commodity and waterways become life support systems (fishing, watering of livestock, irrigation for crops, recreation, etc.), providing water for domestic use and irrigation and supporting transport systems.

High sandy river banks, essential for crocodile ecology, are also good fishing camps and village sites, therefore fishermen activities had a severe influence on the nesting success of crocodiles and on the crocodiles themselves. Illegal hunting practices lead to huge areas of destroyed natural habitat, seconded by illegal trades of hatchlings and/or skins.

Recently, it was observed a severe reduction in the number of adult individuals due to the direct threats. From this study will benefit the scientific and conservation management communities, both nationally and internationally, by creating a comprehensive management plan to control the Nile crocodile life threats in Nasser Lake area. Finally, the low numbers of breeding length adults and a decrease in nest numbers, combined with the associated human activities occurring in lake Nasser area, has led to the question of what influence humans are having on crocodile population due to the disturbance associated with their specific habitats. 
The aim of the study is to indicate crocodile habitat/nesting habitat suitability in relation to human disturbances, in order to have the remained suitable habitat protected in the form of a proposed sanctuary based on a GIS framework.

The objectives of the present study are to:

- record all available nesting preferences of crocodiles in lake Nasser by carrying out a thorough diurnal and nocturnal survey of all the available nesting sites;

- create a habitat suitability map based entirely on nesting requirements and ecological criteria obtained from the nesting survey, factors such as distance from water, vegetation structures and location on the lake Nasser are taken into concern;

- establish habitat vulnerability by determining the difference between the habitat suitability map and the habitat disturbance map, which will indicate the extent of nondisturbed or available habitat remaining in the system.

Indentify the remaining suitable habitat (vulnerable) for protection designation in the form of a proposed sanctuary or a nature conservation sector, in order to put lake Nasser as a whole under the protection of the law.

\section{MATERIALS AND METHODS}

\section{Georeferences and image rectification}

Geographic coordinates of sites were determined by a GPS e Trix H as UTM WGS 1984. The Landsat ETM+ satellite images were rectified using a topographic map $(1: 50,000)$ of lake Nasser using ERDAS 9.2 and Arc map 9.1. I used Image to Image rectification using Geometric Correction Tool, recorded GCPs and resample the image. The GCPs were digitized and spread out across the image to form a large triangle. After we digitized the fourth or more GCPs in the first Viewer, the GCP is automatically matched in the second Viewer. This occurred with all subsequent GCPs that were digitized. ERDAS IMAGINE 9.1 automatically updates the transformation on the screen, thus making possible to make visually based judgement for the result as the set of GCPs are changed. Since the true error of each individual position is unknown, the sampling to obtain an optimal set of GCPs was done by "trial and error" until the root mean square (RMS) error was minimized at the same time as the fit between the image and the full reference data set was maximized. ArcGIS 9.2 was used for rectification of the images, in order to set a higher accuracy for the rectification process.

\section{Satellite Data}

Landsat ETM+ data and aster images acquired in 2009 (Fig. 1) with ground resolution of $30.0 \mathrm{~m}$ false color composite (FCC) of Eight bands (Tab. 1) was used for Nile crocodile habitat features extraction and modeling purpose.

Table 1: Features of Landsat ETM+ sensor.

\begin{tabular}{|c|c|c|}
\hline Bands & Wavelengths $(\mathrm{m} / \mathrm{s})$ & Resolution $(\mathrm{m})$ \\
\hline 1 & $0.45-0.52$ & 30 \\
\hline 2 & $0.52-0.60$ & 30 \\
\hline 3 & $0.63-0.69$ & 30 \\
\hline 4 & $0.77-0.90$ & 30 \\
\hline 5 & $1.55-1.75$ & 30 \\
\hline 6 & $10.40-12.50$ & 60 \\
\hline 7 & $2.09-2.35$ & 30 \\
\hline 8 & $0.52-0.90$ & 14.25 \\
\hline
\end{tabular}




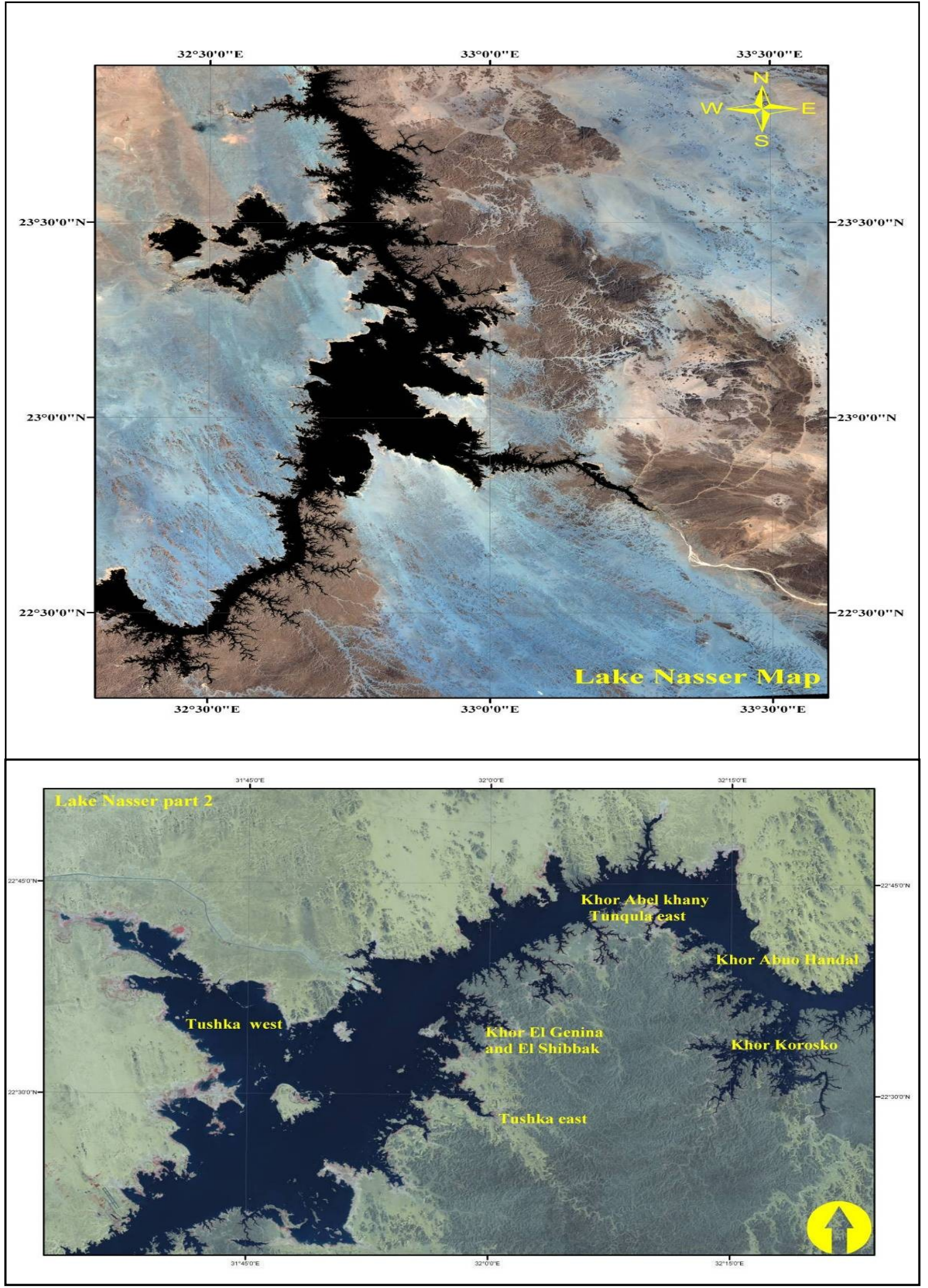

Figure 1: Nasser Lake FCC image. 
Different band combinations of the landsat ETM+ data serve for an easy separation of features of interest: band 1 provides increased penetration of water bodies and also allows differentiation between soil or rock surfaces and vegetation; band 2 is sensitive to water turbidity differences, highlighting turbid water, and, because it covers the green reflectance peaking from leaf surfaces, it is capable of separating vegetation (forest, croplands, etc.) from soil, therefore barren lands, urban areas and roads appear as brighter (lighter) tone, while forest, vegetation, bare and cultivated fields appear as darker tone; band 3 is sensitive in a strong chlorophyll absorption region and strong reflectance region for most soils, distinguishing between vegetation and soil; band 4 and band 5 show a high reflectance in healthy vegetated areas, being helpful in comparing flooded areas and vegetated areas; band 6 (thermal infrared) measures the amount of infrared radiant flux (heat) emitted from surfaces; band 7 is capable of sharply distinguishing land and water; band 8 is helpful for improving image resolution at layer stack process.

\section{Mapping of habitat fitness}

Based on the survey data and habitat suitability parameters, the specific areas which favor the presence of crocodiles can be identified. Due to the large extent of Nasser Lake, these factors were introduced in Arc GIS (ARC Map 9.2) to create an image for habitats and in ERDAS IMAGINE 9.1 to extract areas that are also suitable for crocodiles, based on the data collected from crocodiles survey. The entire dataset was used to create a habitat suitability map, based on the specific spatial habitat requirements of the studied species. The map reveals all areas within the study area, which have suitable values of the environmental variables required for crocodiles. By identifying the difference between the habitat suitability map and the disturbance map, areas with crocodile suitability which are free of any disturbances can constitute a priority conservation map.

\section{Field work and activities}

The fieldwork in Nasser Lake was conducted from October 2009 to August 2010. We censured the crocodile population using spotlight surveys (Bayliss, 1987; Salem, 2010). A five meter fiberglass-boat fitted with an outboard motor 25/15 hp Yamaha/Mariner, was used for every count activity. The boat was always operated at an average speed of about $5-15 \mathrm{~km} / \mathrm{h}$ in order to scan the water and the shoreline of khors for crocodiles' reflective eyes. The speed of the boat was reduced at each sighting, in order to approach slowly the crocodile and estimate their size. The team consisted of four persons, two observers who spotted and counted the crocodiles, a member of the team who recorded the sightings and a boat driver.

The survey started 15-30 minutes after sunset or as soon as it became dark enough to use the spotlight method. A 100,000 to 200,000 Spot flood Q-beam spotlight "Brinkmann", and 12-volt headlights were used. Total length (TL) was estimated for each spotted crocodile, and its position was obtained with a Garmin etrix ${ }^{\circledR}$ GPS 12 .

The purpose of the sampling technique is to estimate the number $(\mathrm{N})$ of individuals present in an area from a sample count $(\mathrm{C})$ of that area, the expected value of the count being given by $\mathrm{E}(\mathrm{C})=\mathrm{N}^{*} \mathrm{p}$, where $\mathrm{p}$ is the detection probability (Nichols et al., 2000).

The nesting surveys were carried out by patrolling shorelines by boat or by foot, as close to the water as possible, looking for specific marks on the sandy shoreline banks, or for occurrence of shrubs/trees of Tamarix nilotica and other related species known as signs of potential nesting sites. 
Environmental parameters were recorded at each site: date and nest number; location name and position; vegetation coverage and type; distances to water $(\mathrm{m})$; height above water (m); the amount of direct sunlight received by each nest, estimated as the daily percentage of direct sunlight on the nest; depth to first egg $(\mathrm{cm})$; depth and breadth of the hole; soil type.

\section{RESULTS}

\section{Nile crocodile presence}

A total of 528 presence points of crocodile locations were recorded by Garmin GPS and the habitat features of the location were noted for data analysis and interpretation. The survey route was plotted on landsat ETM+ maps of Lake Nasser (as shown in the following images), as well as the crocodiles sighting, on the other hand. In all images, the survey routes represented by the yellow/yellowish color line and the white or red represented the crocodiles sighting using Arc map 9.2 software. This image illustrated the buffer zone border as an example of how the buffer zone was estimated at $100 \mathrm{~m}$ in and out of the survey route (maximum distances for the survey tracks and also the distance for maximum point for the nests, based on nesting survey - Annex I).

\section{Database}

The GPS locations of the 528 presence points were converted to UTM WGS 84 Zone $36 \mathrm{~N}$ projections, similar to FCC. Thus, 528 points were used for creating presence location shape files in Arc GIS and overlayed on FCC (Fig. 2) for revealing Nile crocodile's location in lake Nasser, for each location survey during field trips as well as for nocturnal surveys.

The Landsat ETM and FCC with $30 \mathrm{~m}$ ground resolution were used to prepare the land use/land cover map of the study area. We selected the bands $1,2,3,4,5,7$ and 8 of $30 \mathrm{~m}$ resolution (except for band 8, with a $15 \mathrm{~m}$ resolution) and layer stacked for further analysis. Supervised classification technique has been used, with a maximum likelihood decision rule for image classification. The band 6 was cancelled in the layer stack process and supervised classification. The shoreline of the lake Nasser is continually undergoing a wide range of geomorphologic and environmental changes, due to natural causes (water levels, depth, temperature, $\mathrm{pH}$, TDS, conductivity, dissolved oxygen, light transparency, phosphate, nitrate, nitrite, ammonium, sulphate, hydrosoil phosphate, nitrate, nitrite, ammonium, organic matter; watersand dunes movement, erosion, climatic changes) and to human activities (settlements, agriculture, fishing, industrial activities, tourism and recreational activities, wastes disposal). (Yacoub, 2009; Salem, unpublished data)

For an effective use of the land cover map in the modeling process, we defined cover classes that were relevant for Nile crocodile: 1) Water, 2) Sand Sheets, 3) Sandy areas, 4) Granite Mountains, 5) Basement rocks and 6) Vegetation, subdivided into natural vegetation and agricultural fields. The classification system focuses on land-cover classes that can be discriminated primarily from satellite remote sensor data.

\section{Land covers classification (Supervised classification)}

The supervised image classification was performed to generate land cover classes, and thus the classification map targeted to model the habitat suitability for Nile crocodile (Fig. 3).

Based on image classification, it was observed that Tamarix nilotica and other natural vegetation types represented $606 \mathrm{~km}^{2}(7.6 \%)$ of the subset image, cultivated land around lake Nasser shoreline about $26.7 \mathrm{~km}^{2}(0.33 \%)$, areas with basement rocks about $1,122 \mathrm{~km}^{2}(14.1 \%$ of the subset image), sandy areas represented $2,675 \mathrm{~km}^{2}(33.6 \%)$, sandy sheets about $595 \mathrm{~km}^{2}$ (7.5\%), granite areas represented $239 \mathrm{~km}^{2}(3 \%)$, water bodies, about $2,615 \mathrm{~km}^{2}(33 \%$ of the selected area for classification) and desert wadis, $81 \mathrm{~km}^{2}(1.1 \%$ of the selected area for classification). All image classifications were carried out for the larger partition of the lake. 


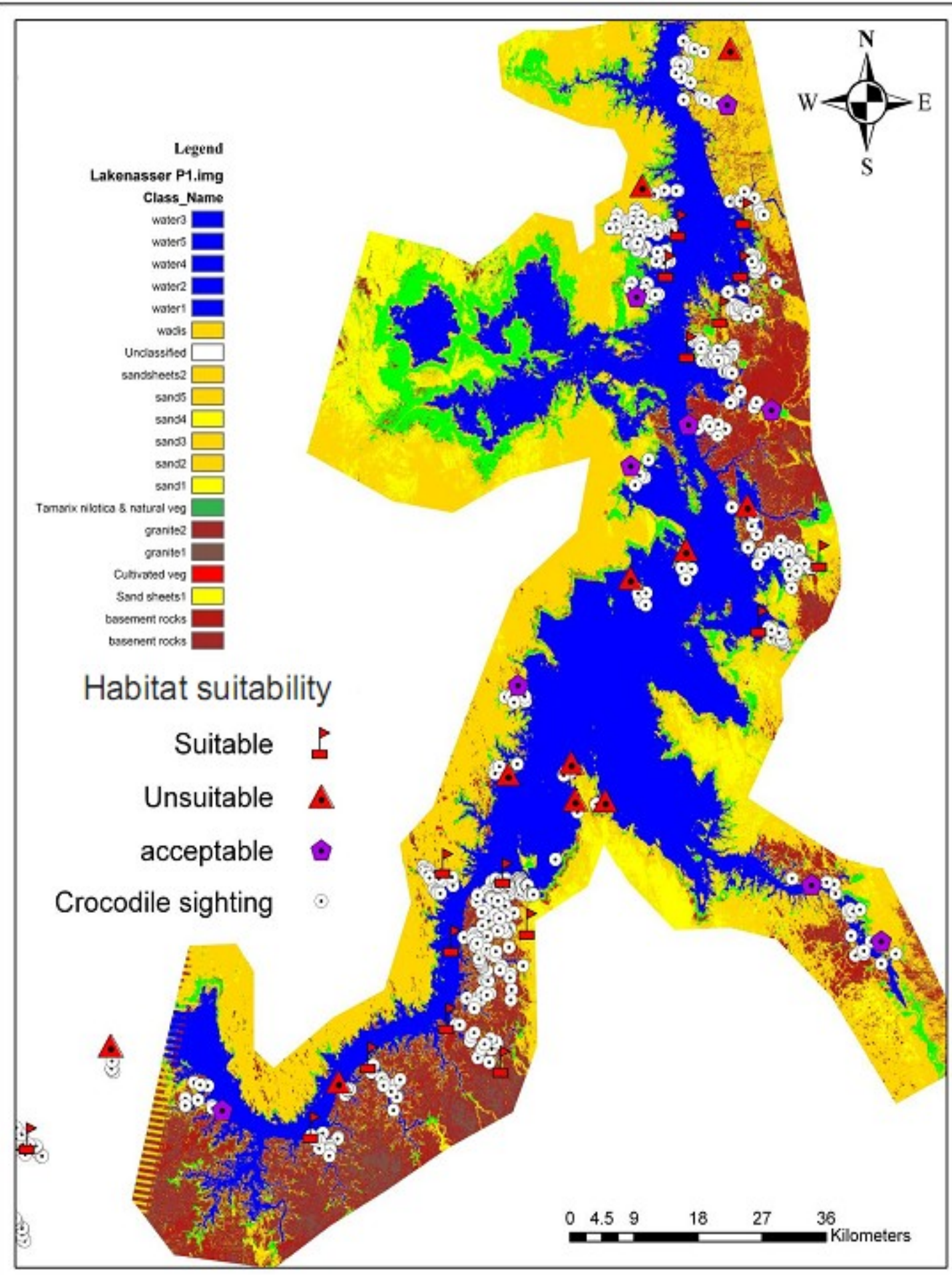

Figure 2: Nasser Lake land cover map/vegetation map, based on supervised classification. 
Based on the nocturnal spotlight survey and the supervised classification scheme of classification, areas with $0-5 \%$ occurrence probability were considered as unsuitable, areas with $5-20 \%$ probability were considered as acceptable (moderately suitable), and areas with over $20 \%$ (up to around $75 \%$ ) species occurrence probability were considered as suitable habitats (Fig. 3). Briefly, they can be reclassified into two classes - unsuitable $(0-5 \%$ occurrence probability) and suitable (5-75\% occurrence probability).

While suitable habitats include areas currently being used by the Nile crocodile and the areas that could be potentially used (mostly all other land cover types that were in proximity to natural vegetation), the settlement and agriculture areas, fishermen camps, steep and rocky shorelines were classified as unsuitable habitats for the crocodiles.

\section{DISCUSSION}

Evaluation of potential area for Nile crocodile can be considered as one of the most important steps towards the conservation of the Nile crocodile in Nasser Lake, as well as the first step towards a true management for the Nile crocodile.

The conservation of the Nile crocodile populations and the effective management of their habitats depend mainly on our ability to recognize and predict species-habitat interactions. Intensive ground surveys cannot keep pace with the rate of land use change and, consequently, habitat composition changes over large areas. We explored how effectively do remote sensing satellite imagery and GIS modeling technique can be used for assessing habitat suitability of Nile crocodile in lake Nasser and which are the habitat factors influencing Nile crocodile distribution in lake Nasser.

The spatial relationship between vegetation types and soil types, the availability of the shoreline, the areas with less and no human disturbance influence the abundance and progress/regress of the Nile crocodile.

The study of the relationships between species and their environment has been traditionally a central issue in ecology and is, at the moment, one of the most important aspects in conservation and management planning of the Nile crocodile in the Nasser Lake. However, dynamic properties of animal distribution can rarely be reflected accurately in a static map, even though we have a good knowledge of the species biology. Moreover, human and logistic limitations make unreasonable the surveillance of large areas and, inevitably, our knowledge of the spatial distribution of most species will have many gaps. Seone et al. (2004) discussed the problem and concluded that the common solution to this problem is to resort the predictive habitat modeling and regard the results concerning the potential habitat, which can be reached and colonized by a species.

Interactions between organisms and their biotic and abiotic environmental conditions strongly influence the habitat use, the spatial habitation of species, and the proportion of each species within the community, and thus, the community composition and structure. In accordance with that, our study results have shown that the areas of sand and sandy-rocky or alluvial deposits-rocky, and other mixed areas which characterize the end part of the khors are the important areas for crocodile presence, and both the GIS analysis and field results confirmed this hypothesis.

Finally, as human population increases in size and demands more resources, their expansion happens in a detrimental way for wildlife habitat (Mwalyosi, 1991). Wildlife management and conservation initiatives are only possible with the appropriate information on wildlife and its habitat. The case of Nasser Lake is not an exception, fact proved by the increasing demand of fishermen for space and resources, the destruction of nests and suitable habitats for crocodiles and by the need to control the number of crocodiles in the lake. 
Areas with aquatic vegetation, sandy or alluvial soils, slopes under $30^{\circ}$ and low human impact are the best areas for hatchling of the Nile crocodile and that was emphasized by old field works made by the author and is similar with the reports of Hutton (1984) and Botha (2005). Therefore, the availability of contiguous aquatic and semi aquatic vegetation and natural vegetation on the lake's shoreline, along with a sufficient distance from disturbing factors are considered to be suitable conditions for the crocodile's presence.

These parameters can be detected in appropriate resolution satellite imagery, with clear distinction between the features of interest. Landsat ETM+, which was used by the author, because of its availability, is limited to a maximum resolution of $14.25 \mathrm{~m}$, which, at the size of Nasser Lake, may produce some estimation errors.

The results, however, allowed us to create a habitat suitability map based on the ecological factors and disturbance factors, such as fishermen activities occurrence, boats traffic, human disturbance (tourism, agricultural activities, pollution, etc.), settlements, etc. Such disturbances are shoreline erosion, pollution from motor boats and other engines, noise effect due the boat traffics and disturbances of the vegetation and of other environmental variables related with the crocodile presence.

It was observed the fact that the boats passing close to nests creates significant noise and disturbance especially for crocodile females, who quickly enter in the water. According to Nasser Lake authorities, most areas are sometimes crowded by fishermen, this meaning associated noise which represents an important disturbance for nesting crocodiles, especially at the end of the local khors, where suitable nesting habitats are generally found. Field investigations proved that at least one of every eight boats carries and engine, which, along with noise disturbance, is a source of pollution, due to emissions and oil or fuel spills, which impact the aquatic vegetation and the entire local food chain. Agriculture related substances, such as fertilizers and pesticides, also play their role in the local pollution and habitat degradation.

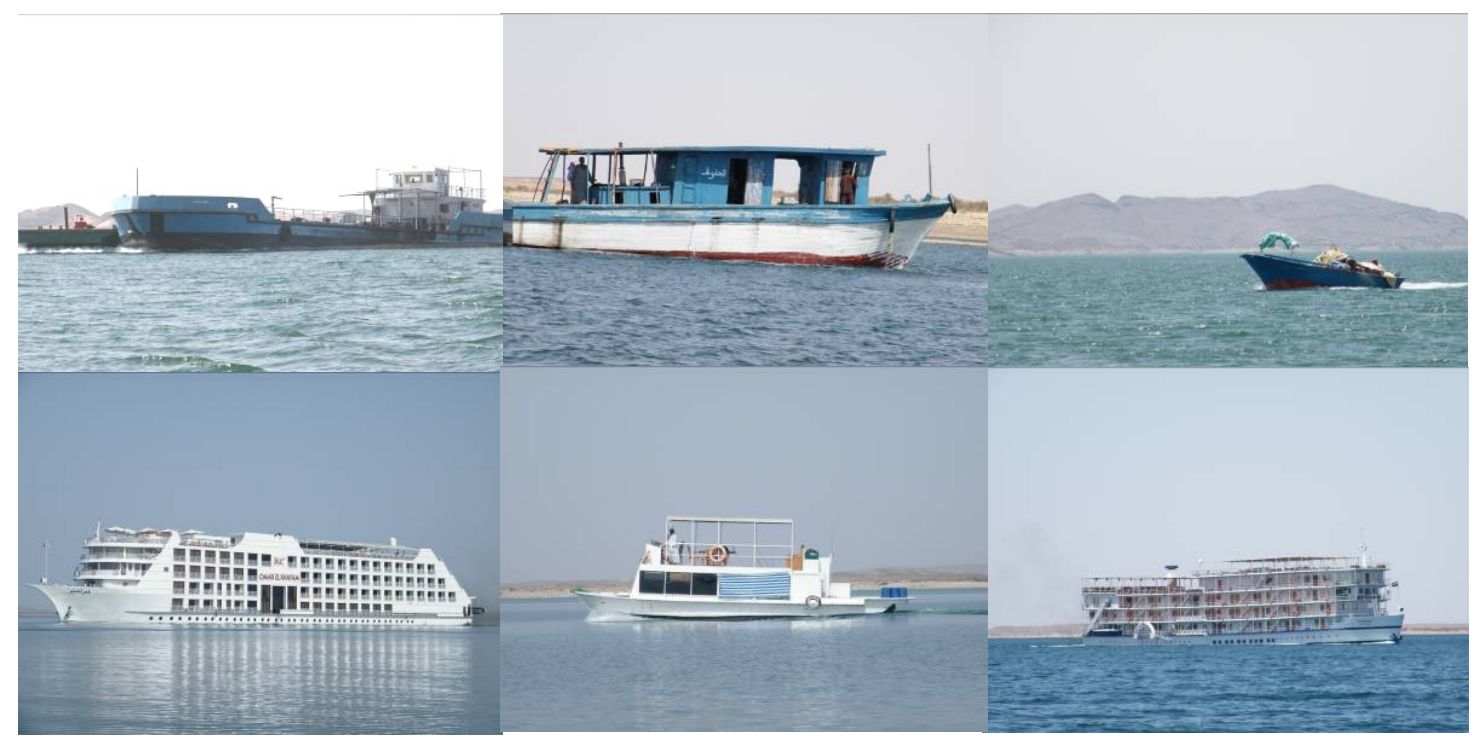

Figure 3: Touristic boats moving on Nasser Lake. 
Tourism related impacts represent one of the human impact growing disturbance for crocodiles nesting in the Nasser Lake system. It was noted the fact that during the expedition, cruise ships and tourist boats can quickly produce high waves (Fig. 4), which are eroding the sandy shorelines, one of the suitable areas for the crocodiles. This is in accordance with similar investigations made by Mbaiwa (2002), who studied environmental impacts of tourism development on the Okavango Delta, finding that a major impact on wildlife in that delta was caused by the increased boat traffic on the river.

In the last ten years, with the increasing demand for fish and with the increases in the market price for such fish, fishermen used nets and advanced fishing equipments for large quantities of captures (Fig. 5), restricting in this way the movements of crocodiles in khors. The result has been the radical decrease of crocodile ways and paths number, hence the numerous fishermen claims that the crocodiles destroyed fishing equipments and fishing nets, this being a good reason for killing the crocodiles.

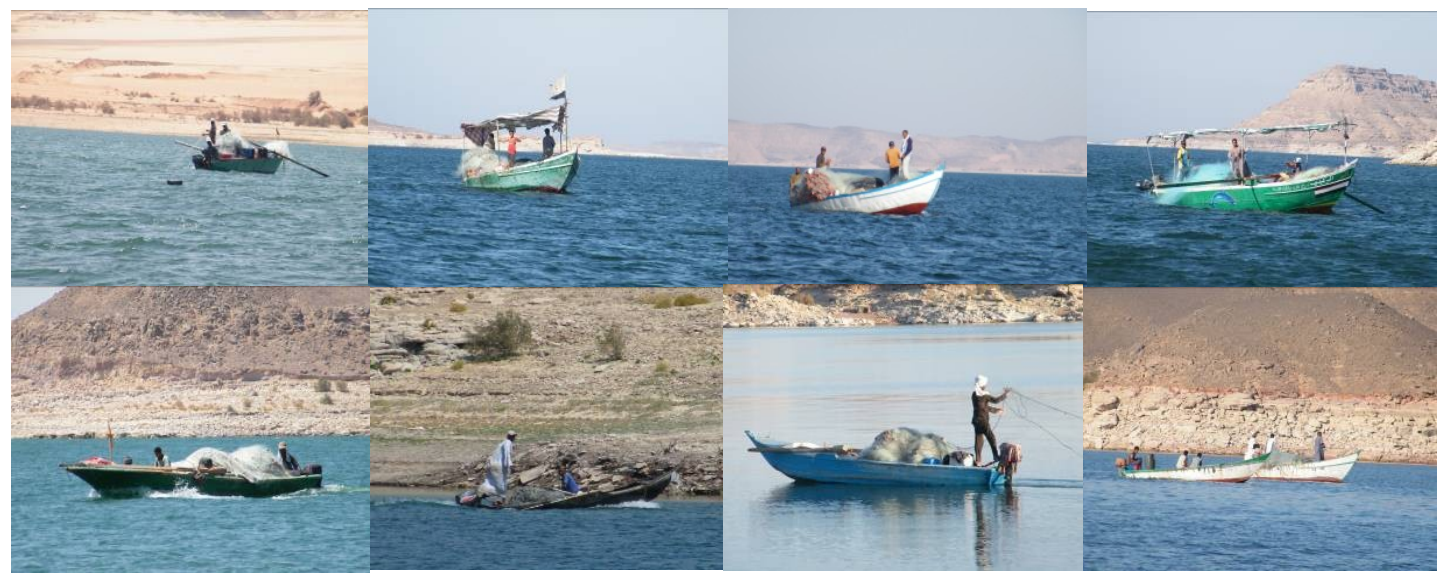

Figure 4: Fishing boats on Lake Nasser.

Based on Bishai et al. (2000) and personal observations (Salem, 2006), it is known that the water level of the lake reaches its maximum in November and December, and then drops gradually till July. The water level drop gives the local inhabitants (Bedouins) and farmers access for grazing and agriculture; unfortunately, these agriculture lands are mostly located on sandy shorelines (Fig. 6), which are a suitable habitat for crocodile nesting.

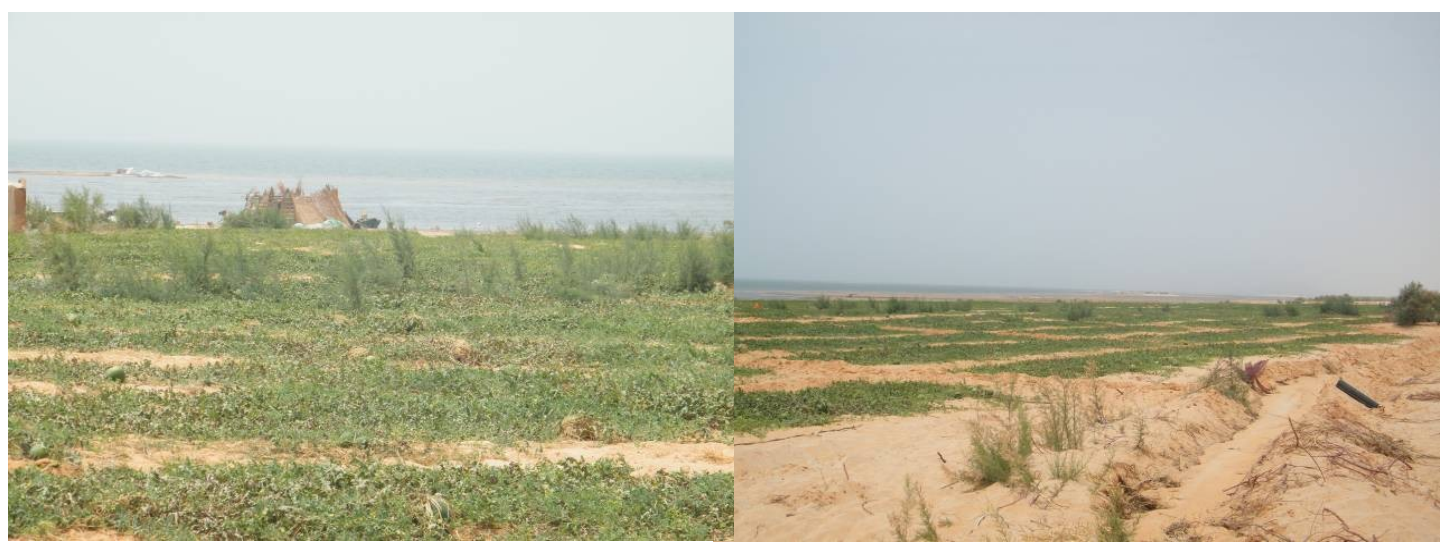

Figure 5: Agricultural landscape on the shores of Lake Nasser. 
Fishing is the main activity that influences shoreline areas, and continues throughout the crocodile nesting period, not being influenced by water levels, as are other activities, like grazing and agriculture. On the other hand, the Nasser Lake fishermen are known to destroy crocodile eggs and nesting sites (Leslie, 2003). Cassidy (2003) reported that humans and crocodiles naturally come into conflict over certain resources, and the damage of this keystone species will have very severe implications for the ecosystems and for the people relying on them for resources. Therefore, I recommend that the human impacts on crocodile habitats in Nasser Lake must be evaluated and monitored, for the sake of both species and the ecosystem on which they rely, and stress the need for further research, as well as for a stronger control and awareness on this problem.

\section{ACKNOWLEDGMENTS}

Many thanks to the Mohamed Bin Zayed Species Conservation Fund, NCS, South Area Protectorate researchers, EEAA, Mr. McGrath, Mr. Shaltout and the Ecology Department of Tanta University. Special thanks to the Transylv. Rev. System. Ecol. Res. editors for their continuous support.

\section{REFERENCES}

1. Bayliss P., 1987 - Survey methods and monitoring within crocodile management programs, in Webb G. J. W., Manolis S. C. and Whitehead P. J. (eds), Wildlife management: crocodiles and alligators, Surrey Beatty and Sons, Sydney.

2. Bishai H. M., Samir A. A. M. and Magdy T. K., 2000 - Lake Nasser, Cabinet of Ministers, State Ministry of Environment, Egyptian Environmental Affairs Agency.

3. Botha P. J., 2005 - The Ecology and Population Dynamics of the Nile Crocodile Crocodylus niloticus in the Flag Boshielo Dam, Mpumalanga Province, South Africa, M.Sc. Thesis, University of Pretoria, South Africa, 172.

4. Cassidy L., 2003 - Anthropogenic burning in the Okavango panhandle of Botswana: Livelihoods and spatial dimensions, M.Sc. Thesis, University of Florida, Miami.

5. Hutton J. M., 1984 - The population ecology of the Nile crocodile, Crocodylus niloticus Laurenti 1768, at Ngezi, Zimbawe, Ph.D., Thesis, Univeristy of Zimbawe, Harare.

6. Hutton J. M. and Games I., 1992 - The CITES Nile Crocodile Project, Secretariat of the Convention on International Trade in Endangered Species, Lausanne, Switzerland.

7. Leslie A. J., 2003 - Okavango Crocodile Research Project: Progress Report \#1, Department of Conservation Ecology, University of Stellenbosch.

8. Mbaiwa J., 2002 - The socio-economic and environmental impacts of tourism development on the Okavango Delta, north-western Botswana, Journal of Arid Environments, 54, 447-467.

9. Mwalyosi R. B. B., 1991 - Ecological evaluation for wildlife corridors and buffer zones for Lake Manyara National Park, Tanzania, and its immediate environment, Biological Conservation, 57(2), 171-186.

10. Nichols J. D., Hines J. E., Sauer J. R., Fallon F. W., Fallon J. E. and Heglund P. J., 2000 - A double-observer approach for estimating detection probability and abundance from point counts, The Auk, 117(2), 393-408.

11. Salem A. H. I., 2006c - Demographic study on the woody vegetation in Wadi Allaqi, South Eastern Egypt, M.Sc. Thesis, South Valley University, Aswan.

12. Salem A. H. I., 2010 - Nocturnal spotlight count survey methods for the estimation of abundance, distribution and population trend analysis of the Crocodylus niloticus in Lake Nasser, Transylvanian Review of Systematical and Ecological Research, Curtean-Bănăduc et al. (eds) $10,107-136$.

13. Seone J., Bustamante J. and Diaz R., 2004 - Competing roles for landscape, vegetation, topography and climate in predictive models, Ecological Modeling, 171(3), 209-222.

14. Yacoub H., 2009 - Najas ssp. growth in relation to environmental factors in Wadi Allaqi (Nasser Lake, Egypt), Transylvanian Review of Systematical and Ecological Research, Curtean-Bănăduc et al. (eds), 8, 1-40. 
Annex I; Trip 1.

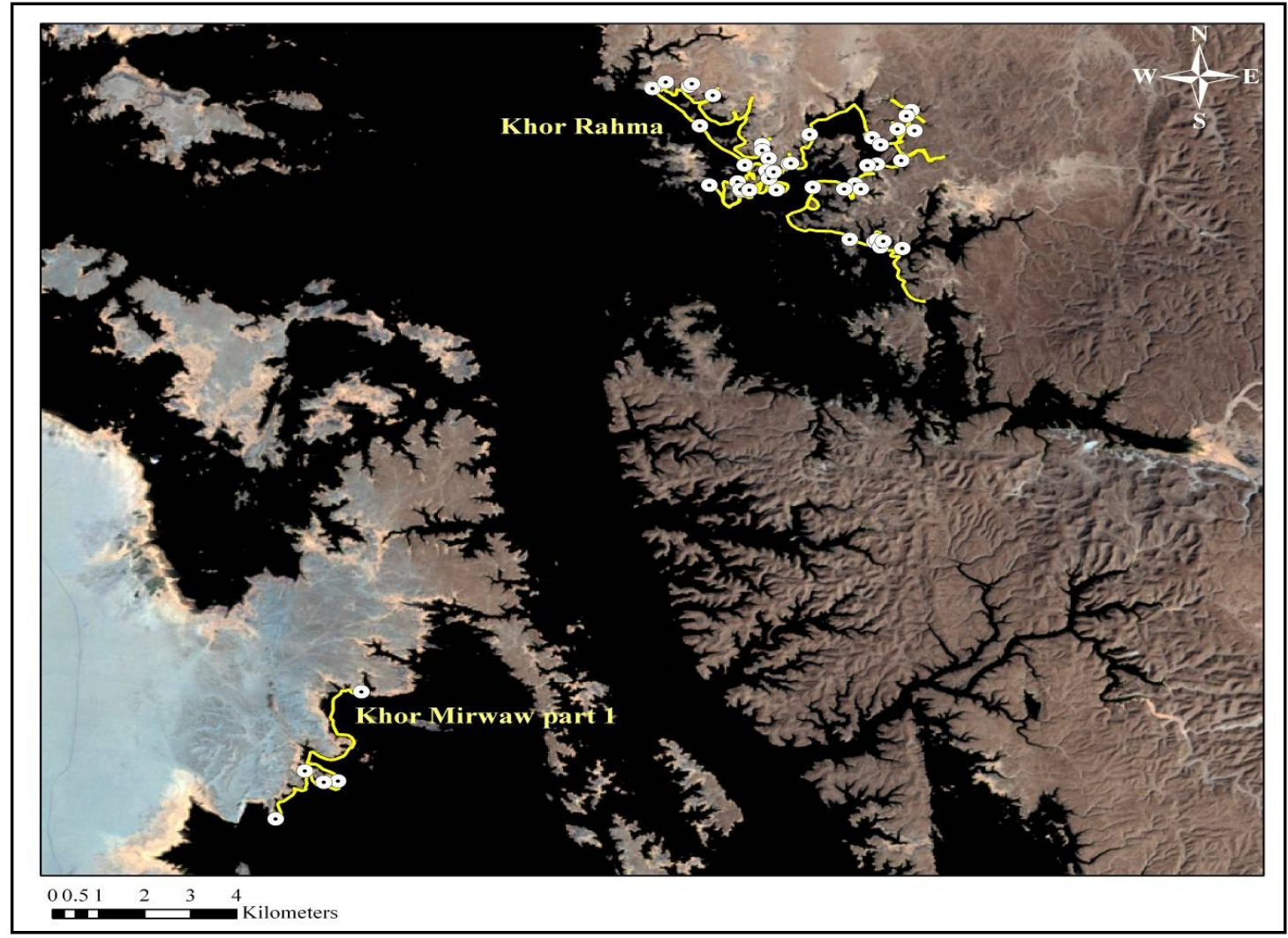

Annex I; Trip 2.

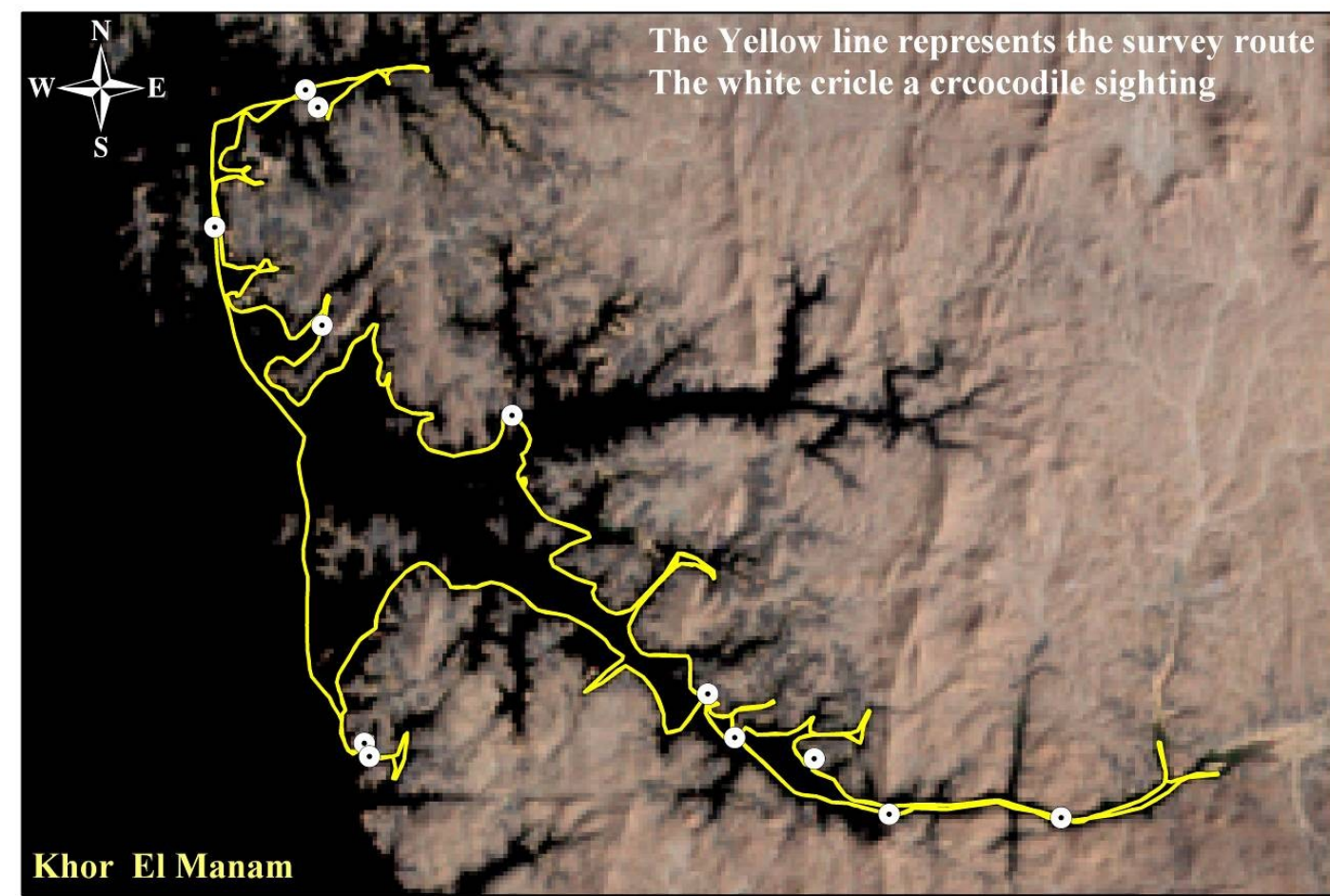

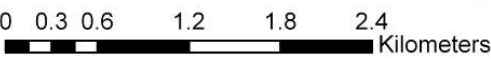


Annex I; Trip 3.

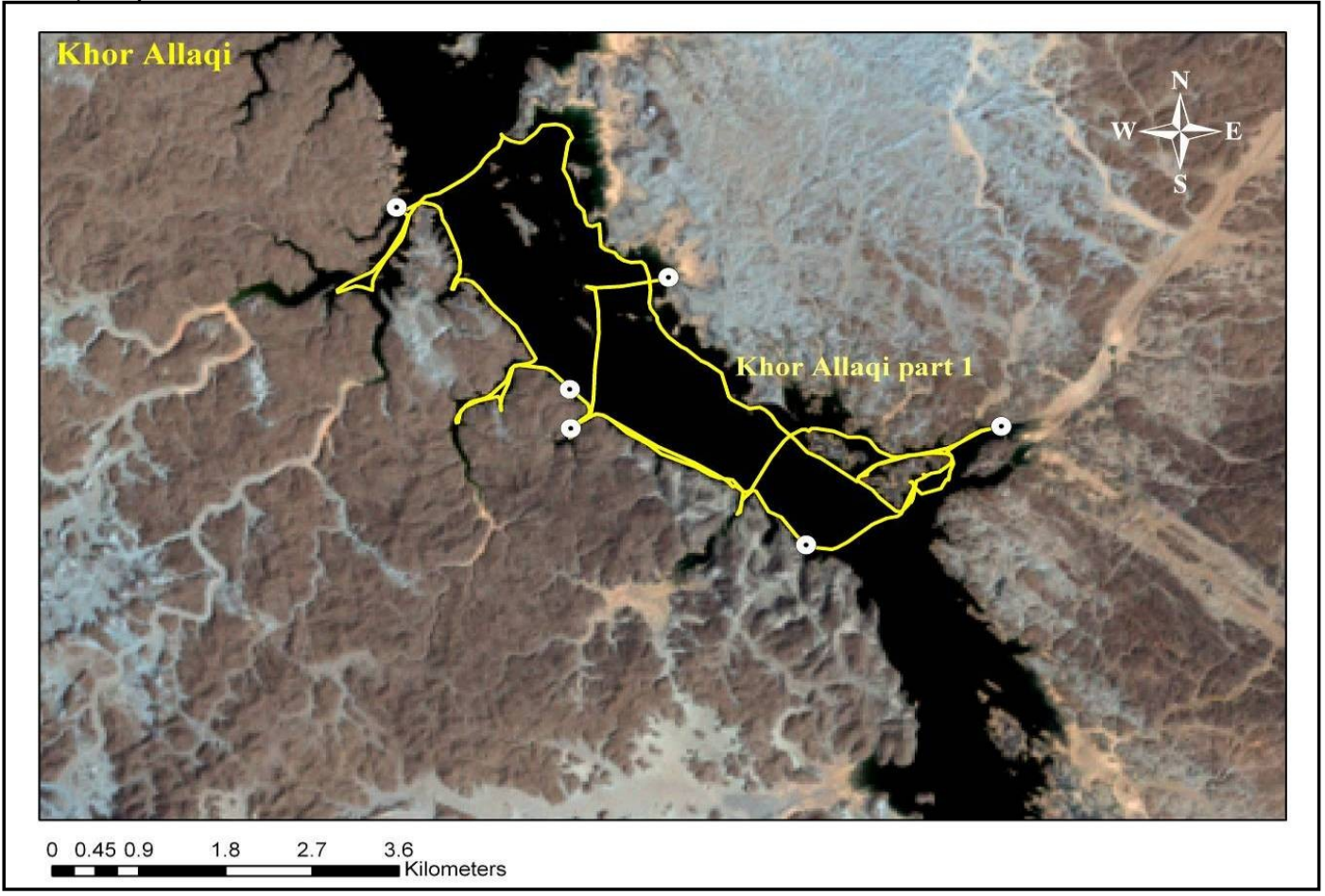

Annex I; Trip 4.

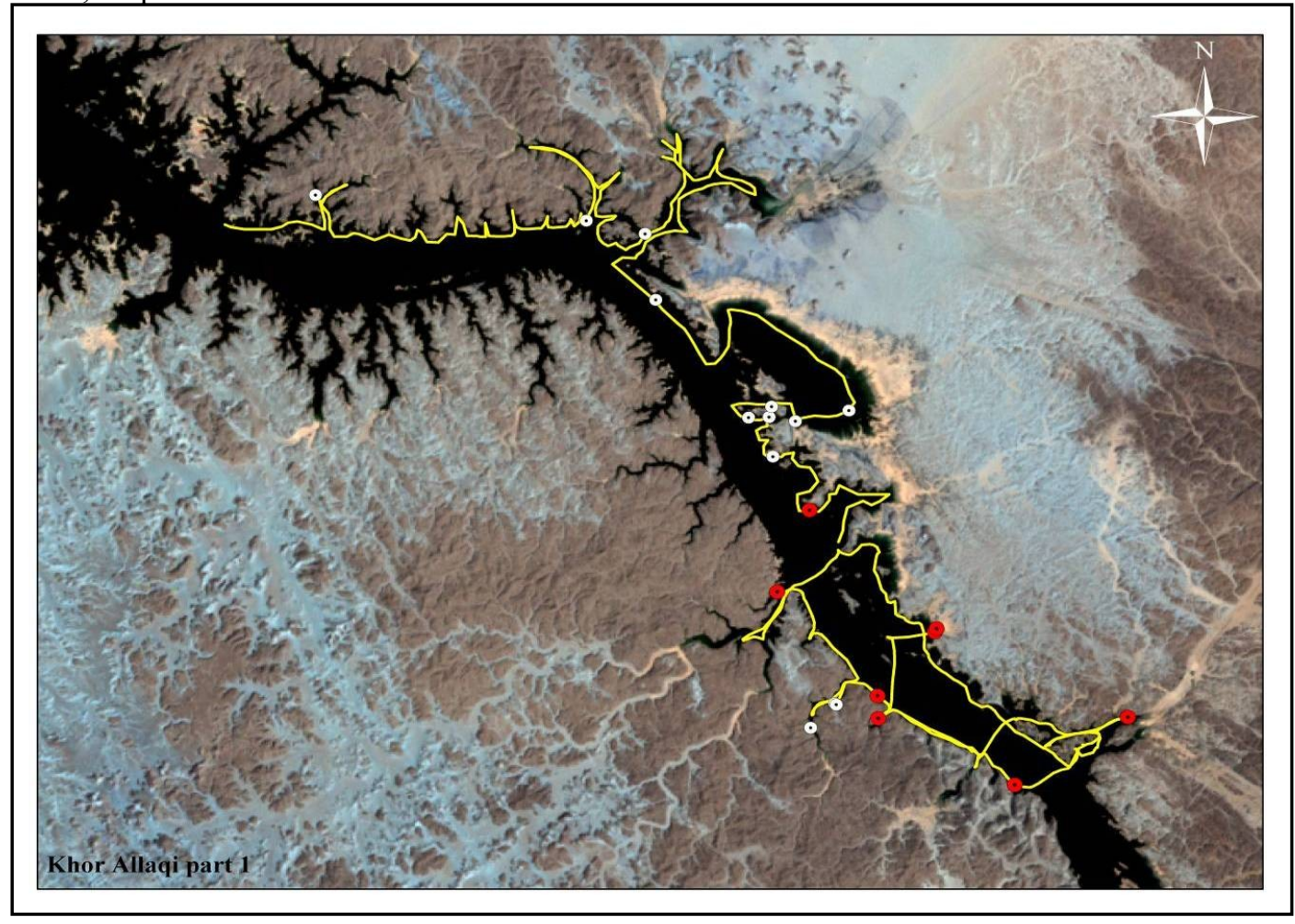


Annex I; Trip 5.

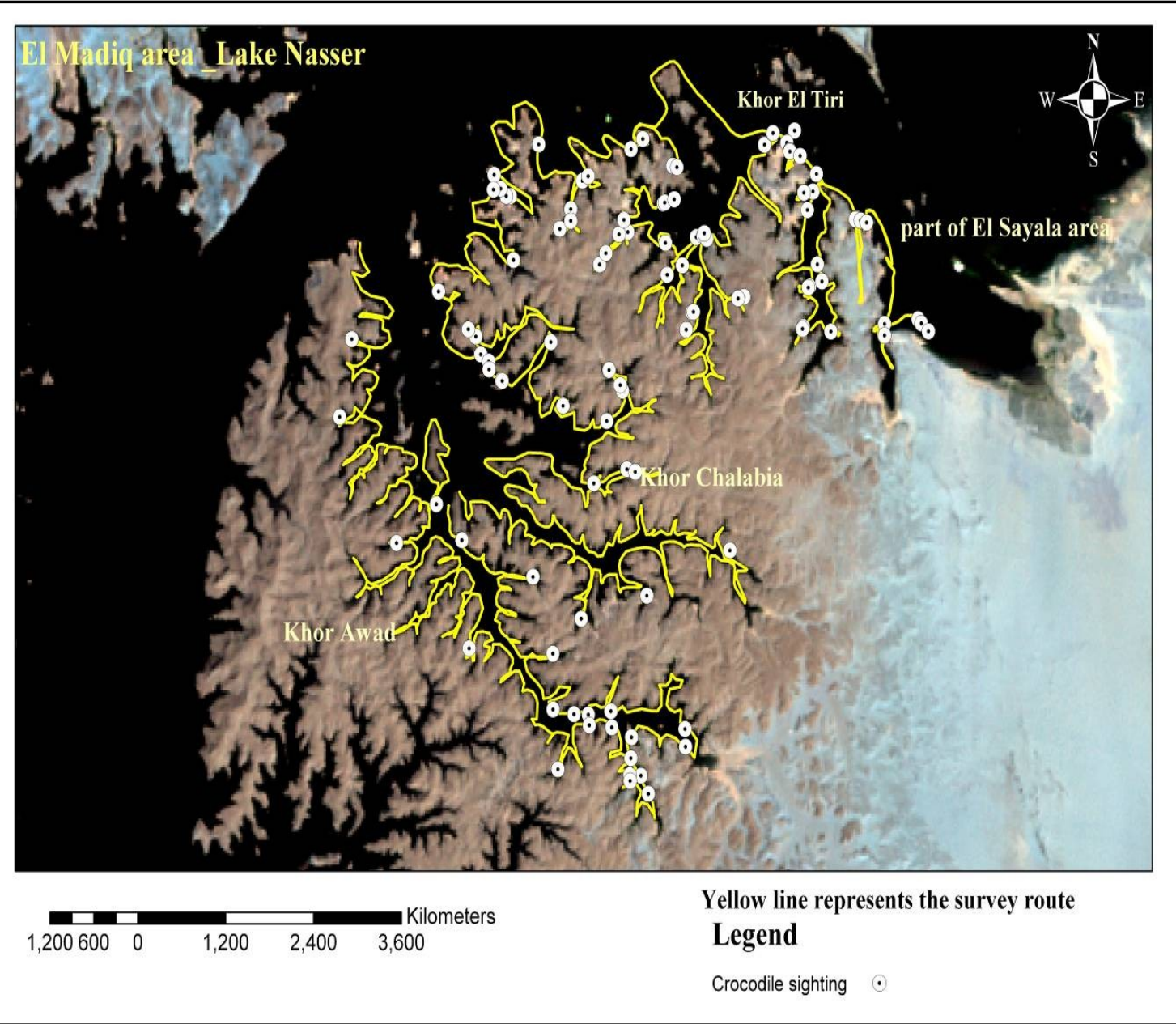

